\title{
Human resource management practices and nursing turnover
}

\author{
Kent V. Rondeau ${ }^{* 1}$, Terry H. Wagar ${ }^{2}$ \\ ${ }^{1}$ School of Public Health, University of Alberta, Edmonton, Canada \\ ${ }^{2}$ Department of Management, St. Mary's University, Halifax, Nova Scotia, Canada
}

Received: March 2, 2016

DOI: $10.5430 /$ jnep.v6n10p101
Accepted: May 16, 2016

Online Published: June 13, 2016

\begin{abstract}
Background: The objective of this study is to explore the nature of the association of discrete systems of human resource management practices and the rate of voluntary turnover of registered nurses (RNs) in a large sample of Canadian acute care hospitals and nursing homes. Healthcare quality, cost and access are impacted by excessive turnover of nursing staff. The rate of annual turnover for registered nurses has been estimated to be about 20 percent in Canada, with a total cost of almost $\$ 27,000$ for each RN. Healthcare organizations that employ large numbers of registered nurses are keen to learn more about the role that organizational policies and practices play in reducing voluntary turnover. The relationship of human resource management (HRM) practices and employee turnover has generally been under-investigated. Three HRM systems, composed of bundles of discrete workplace or employment practices, were conceptualized in order to assess the relationship of HRM practice systems with the rate of RN turnover, at the establishment or facility level. Three HRM practice systems were constructed to test their systemic impact on nursing turnover: a technical HRM system that focuses on bureaucratic policies and practices that regulate the employee-employer relationship; a quality-of-worklife HRM system that includes a variety of employee-centered and family-friendly employment practices; and a high-involvement HRM system that utilize workplace arrangements that increase the commitment, engagement, accountability and participation of nurses.

Methods and analysis: The chief nursing officers of 2,208 Canadian hospitals and long-term care facilities received the study questionnaire, generating responses from a total of 705 establishments. Each of the three HRM practice systems is estimated at each facility and comprised eight (8) discrete employment or workplace practices. Using estimates of voluntary RN turnover as the dependent variable, a step-wise ordinary least squares (OLS) regression was performed on each HRM practice system.

Results: After controlling for facility characteristics and for local labour market conditions, the quality-of-worklife HRM employment system $(p<.05)$ and high-involvement HRM work system $(p<.05)$ are found to be related with lower voluntary turnover, yet their overall relationship with facility RN turnover appears to be quite modest. Our technical HRM practice system is not found to be associated with facility RN turnover.

Conclusion: HRM systems comprising employee-friendly employment practices and high-involvement work practices may play an important (but modest) role in reducing $\mathrm{RN}$ turnover.
\end{abstract}

Key Words: Nursing turnover, Human resource management practices

\section{INTRODUCTION}

Healthcare cost, quality and access are impacted by high levels of nursing turnover. ${ }^{[1,2]}$ The cost of nursing staff rep- resents one of the most expensive line items in the budget of healthcare organizations. Excessive nurse turnover is a major global problem that continues to adversely impact

*Correspondence: Kent V. Rondeau; Email: kent.rondeau@ualberta.ca; Address: School of Public Health, University of Alberta, Edmonton, Canada. 
the healthcare system in many countries. ${ }^{[3]}$ Indeed, annual nurse turnover rates range from $15 \%$ in Australia, $20 \%$ in Canada, and $27 \%$ in the United States. The cost of replacing each 'lost' nurse has been calculated at US\$48,790 in Australia, \$26,652 in Canada, and \$20,561 in the United States. ${ }^{[4]}$ Turnover rates are generally much higher among new hires and for recent nursing graduates. ${ }^{[5]}$

Jones, ${ }^{[6,7]}$ in a study of nursing turnover costs, characterizes nursing turnover as the process whereby nursing staff leave or transfer within an institutional environment. While this particular description encompasses both voluntary as well as involuntary aspects of staff loss, turnover has the potential to represent a seminal event for an organization when employees choose to permanently leave their place of employment requiring the organization to address the resultant vacancies. While the evidence assessing the adverse impact of excessive nurse turnover continues to grow, a number of methodological challenges have plagued researchers attempting to measure and capture turnover rates across diverse health systems and jurisdictions. ${ }^{[8]}$

Although some degree of turnover may be beneficial when it serves to renew and revitalize a 'tired' organization and can lead to lower overall operating costs when expensive employees are replaced with less expensive ones, there is a general consensus that high levels of turnover are costly for healthcare organizations, detrimental to well-being and productivity of nurses who remain, and have the potential to affect patient care quality. ${ }^{[9]}$ Financial costs of turnover include both direct financial costs (i.e. advertising and training costs, temporary replacement costs including overtime costs, and hiring costs), as well as indirect costs (i.e. orientation and training costs, lower productivity of new hires, and costs associated with the termination of employment). Nonfinancial costs of turnover also include the loss of human, social and intellectual capital. ${ }^{[10,11]}$ High levels of turnover have the potential to compromise care when nursing staff shortages end up lowering the quality of patient care.

While nursing turnover can be affected by a number of external labour market factors, ${ }^{[12]}$ it is more often directly impacted by a host of internal characteristics, including organizational and workplace climate. ${ }^{[13]}$ Turnover has the potential to impact workplace productivity in that it often accelerates changes in staffing numbers and mix while increasing the use of 'non-standard' employees, as well as nurse auxiliary personnel, part-time staff, and temporary (agency) nurses. As a consequence, excessive turnover gives rise to even more exiting behaviours as nurses become emotionally and physically compromised as they try to cope with having fewer and less experienced colleagues available to manage the same workload.

Turnover is usually superceded by individual intentions to leave an organization, and is more often seen in workplaces with high rates of absenteeism, work-related stress, burnout, and job dissatisfaction. ${ }^{[14,15]}$ Takase, Yamashita and $\mathrm{Oba}^{[16]}$ describe turnover intention for nurses as involving a multi-stage process consisting of cognitive, affective, and behavioural components. Factors such as deep friendships at work, and the lack of opportunities elsewhere, may serve to counteract feelings of job dissatisfaction and act to keep a person on the job. ${ }^{[17]}$ Turnover intent may be impacted by a favorable management style and by leadership characteristics. Raup, ${ }^{[18]}$ in a study of emergency room nurses, found that a transformational leadership style is associated with lower rates of turnover.

Nursing turnover has been conceptualized as an intermediary, throughput factor that has a mediating effect between system inputs and outputs. ${ }^{[19]}$ Numerous studies have identified personal, workplace, organizational and market factors associated with nursing turnover. Findings of relevant research studies have been summarized by Hayes and associates and by Chu and colleagues. ${ }^{[20]}$ Individual determinants of nurse turnover that have been extensively investigated are job satisfaction, age, education, professional orientation, psychological empowerment and job tenure. Workplace factors associated with nurse turnover include total workload, job scope, the degree of job embeddedness, as well as managerial factors. Organizational factors associated with turnover are human resource employment policies and practices, including training and career development options and promotional opportunities, while market factors relate to the relative abundance of alternate employment opportunities. To date, human resource management employment and workplace policies and practices have not been extensively investigated with respect to their potential to reduce nursing turnover.

\subsection{Human resource management practices and turnover}

In response to the longstanding criticism that human resources management (HRM) adds little value to organizations, much academic research that has occurred in the past 20 years that has sought to show that HRM practices are drivers of organizational performance. ${ }^{[21]}$ Indeed, Huselid's ${ }^{[22]} 1995$ groundbreaking study demonstrated that a set of HRM practices he called 'high performance work systems' are related to accounting profits, the market value of the for-profit organization, and to turnover. Combs and colleagues $^{[23]}$ in a meta-analysis including 92 studies on the HRM-firm performance relationship found that a one standard deviation increase in the use of high performance work 
practices is associated with a $4.4 \%$ decrease in turnover.

While the performance effect of individual HRM practices has been extensively examined with somewhat mixed results, it is the combined, 'systemic effects' that are crafted through the production of discrete 'practice bundles' whereby individual practices act synergistically with other practices. ${ }^{[24]}$ It may be that the impact of HRM practices on performance occurs only when a combination of these practices, comprising a coherent HRM system, is concurrently adopted. ${ }^{[25]}$ While the application of individual HRM practice systems may be a requirement for a sustained impact on organizational performance, no consensus exists as to which specific practices to include in a particular HRM system, nor is there even agreement with respect to what constitutes a discrete HRM system. Nevertheless, a number of researchers have conceptualized the relevance of discrete HRM practice systems and have postulated their potential impact on performance. Research has begun to focus on defining and measuring combinations of HRM policies and practices that constitute a firm's HR system and demonstrating a relationship of this system and organization-level performance outcomes. ${ }^{[26]}$ For instance, Toh, Morgeson and Campion, ${ }^{[27]}$ in a study of 661 US organizations, identify five major HRM systems-cost minimizers, contingent motivators, competitive motivators, resource makers, and commitment maximizers. Each HRM system is thought to have discrete consequences for various aspects of organizational performance.

In this study, we have postulated the existence of three distinct HRM systems that can exist (to varying degrees) in organizations: a technical (bureaucratic) HRM system, a quality-of-worklife HRM system, and a high-involvement HRM system. While most healthcare organizations have elements of all three HRM systems, it is postulated that voluntary nursing turnover will be more greatly 'influenced' in those facilities where certain HRM systems predominate. We will examine each of these three HRM systems in turn with respect to their ability to reduce nursing turnover.

\subsubsection{Technical HRM systems}

A technical HRM system is composed of work and bureaucratic employment practices that serve primarily to regulate the employer-employee relationship. Examples of technical HRM practices include the use of employee orientations (for new hires), formal employee performance appraisals, and the existence of written job descriptions for nursing staff. These employment and work practices are routinely and commonly used in many healthcare organizations, serving primarily to improve the efficiency of human resources and to regulate the employment relationship. For the most part, technical HRM practices are bureaucratic, commonly occurring, and are non- strategic in nature. While larger healthcare establishments may be more likely to have a more embedded technical HRM system, employees are generally indifferent to the use of the practices. It follows from this that:

Hypothesis One: Healthcare facilities with a strong technical HRM system will not demonstrate lower RN turnover.

\subsubsection{Quality-of-worklife HRM system}

A quality-of-worklife HRM system comprises employment practices that are favored by employees and their families. Examples of Quality-of-worklife (QWL) HRM system include the adoption of employee- and family-friendly policies such as flexible work hours, self-scheduling, voluntary job-sharing, and an on-site child care program. Kinship responsibilities involve home obligations for working nurses - spouses, children, and aging parents affect satisfaction (and turnover intention) on the job. In a study of 84 nurses who had voluntarily terminated their employment, Strachota and colleagues ${ }^{[28]}$ found that 19 nurses indicated the reason for leaving as being family-related. Nursing work environments that involve long shifts, overtime, weekends, and night shifts are found to be predictors of anticipated turnover, ${ }^{[29]}$ while nurses' intent to stay is found to be associated with feelings of being valued by administration. ${ }^{[30]}$ Kane $^{[31]}$ showed that nurses who are able to job-share are more likely to demonstrate greater job satisfaction and to remain at work. Administrative interventions that aim to improve the quality-of-worklife are considered imperative to nursing workforce retention. If follows from this that:

Hypothesis Two: Healthcare facilities with a strong qualityof-worklife HRM system will demonstrate lower RN turnover.

\subsubsection{High-involvement HRM system}

A high-involvement HRM system is composed of a number of HRM work practices which increase the engagement, involvement and participation of nurses. Examples of highinvolvement practices include: nursing shared governance, quality improvement teams, merit pay, and suggestions systems. The practice environment impacts work content which influences individual motivation and organizational commitment. Human resource management practices are structural factors that facilitate the empowerment of nursing staff can lead to job satisfaction and to feelings to remain at work. Structural empowerment is the perception of the presence or absence of empowering conditions in the workplace, ${ }^{[32]}$ while psychological empowerment is the employees' psychological interpretation to these conditions. ${ }^{[33]}$ Hauck, Quinn Griffin and Fitzpatrick ${ }^{[34]}$ report an inverse relationship between structural empowerment and anticipated turnover in critical care nurses. Fostering environments that enhance 
perceptions of empowerment can have lasting positive effects on nursing personnel. High-involvement practices increase the degree of felt job-embeddedness experienced. Being more firmly 'attached' to an organization is associated with reduced feelings of intent to leave and to lower overall turnover. ${ }^{[35]}$ Anderson, Corazzini and McDaniel ${ }^{[36]}$ show that reward-based climates, high levels of communication openness are associated with lower turnover in nursing homes. It follows from this that:

Hypothesis Three: Healthcare facilities with a strong high-involvement HRM system will demonstrate lower RN turnover.

Consistent with the 'universalist perspective' with contends that HRM practice systems will produce additive and synergistic effect when combined together, ${ }^{[37]}$ it follows that a stronger impact on turnover can be realized when HRM practice systems are combined.

Hypothesis Four: Healthcare facilities with a strong qualityof-worklife HRM system and a strong high-involvement HRM system will demonstrate much lower RN turnover.

\section{METHOD}

\subsection{Survey participants and procedure}

Ethics approval for this study was secured from the University of Alberta Health Research Ethics Board. A postal questionnaire was sent to 2,208 hospitals and long-term care organizations (nursing homes) operating in all ten provinces and three territories in Canada. Relevant information and addresses for each establishment are found in the Guide to Canadian Healthcare Facilities, 2001-2002, ${ }^{[38]}$ where selection criteria limited our sample set to hospitals and nursing homes with 25 or more staffed beds. The questionnaire and a cover letter were addressed to the person directly responsible for the nursing function at that facility. All participants were informed about the nature of the study and that their participation would be voluntary and confidential. Six weeks after the initial mail-out, the questionnaire was again sent to those organizations that did not respond to the first request for participation. After subtracting the refusals, duplicates, and non-deliverables, 232 hospitals (including those designated as acute, chronic, and rehabilitative), and 473 nursing homes constituted our study sample-a $31.9 \%$ response rate. The degree of non-response bias was investigated by comparing late (second wave) and first responders (first wave) according to organizational size, type and location. Late respondents are more similar to non-respondents than early responders. Later responders are not found to show significant differences with respect to any of these characteristics with earlier responders.

\subsection{Study measures}

The primary goal of this study is to investigate the potential of coherent systems of human resource management practices to be associated with lower voluntary turnover of registered nurses. Three human resource management systems (bundles of HRM practices) were investigated with respect to their potential to reduce employee turnover: a) technical HRM practices, b) QWL HRM practices, and c) high-involvement (HI) HRM practices. A number of establishment factors and market-based factors were controlled-for in our analysis because of their potential to be associated with voluntary employee turnover and the selection of human resource management practices.

\subsubsection{Study variables}

The dependent variable in this study is registered nurse (RN) turnover, and was measured using a four-point scale, where respondents were asked to estimate the annual voluntary turnover rate of registered nurses in their facility (from $1=$ no or little turnover [0-2\%] to $4=$ heavy turnover [ $>25 \%]$ ).

The objective of this research is to investigate the relationship between human resource management practices and voluntary turnover of registered nurses. While each independent practice has the potential to impact employee turnover, the greatest impact of human resource management practices on employee turnover will be observed when these practices are combined or bundled into a coherent practice system. Three HRM practice systems were constructed, each comprising a bundle of eight (8) HRM practices. For each HRM practice, respondents were asked if they had such as practice, and if so, to estimate the percentage of nurses covered by the practice. A nurse technical HRM system scale (Cronbach $\alpha=.53$ ) comprises a discrete bundle (system) of HRM practices in that they are universal (used by almost all organizations), employee-neutral (employees are generally indifferent to their use), and non-strategic in nature (not directly related to the realization of an organization's strategy). The primary purpose of an HRM technical system is to increase the overall efficiency, productivity and accountability of labor resources. Examples of technical practices include the use of employment selection tests, written job descriptions, and formal employee performance appraisal. Our nurse quality of worklife HRM system scale (Cronbach $\alpha=.51)$ comprises a coterie of practices that are considered to be 'humanistic' in nature, inasmuch as they are employeeand family-friendly employment practices designed to improve life-at-work, because they focus on employee welfare both on and off the job. Example QWL practices include employee assistance programs, child care programs, and employee career counseling. Our nurse high-involvement HRM system scale (Cronbach $\alpha=.65$ ) comprises a bundle of HRM 
practices that are generally considered to increase the participation, engagement, and commitment that nurses have with their work. Examples of high-involvement practices include nursing shared governance, employee suggestion systems, and nurse self-managing work teams.

It should be stated that the internal reliability scores, represented by Cronbach alpha, were slightly low for two of our three HRM practice systems. Since reliability scores lower than .60 are problematic, this constitutes a valid, albeit small threat, to the validity of research findings.

\subsubsection{Control variables}

A number of establishment variables were controlled in our analysis because of a potentially confounding relationship with nursing turnover and the implementation of HRM practices. Facility type was controlled because technical complexity and patient or resident acuity levels vary across establishment settings and have the potential to impact turnover as well as human resource management practice choices. Facility size reflects the number of beds in operation (calculated as a natural $\log$ ) and was controlled in our analysis because larger establishments usually have more funds available to invest in developing their human capital in line with providing greater training and development opportunities to staff. Having a formal human resources management department or function may facilitate the implementation of more human resource management practices. Facility location was also controlled because establishments situated in urban places have larger pools of labor from which to employ. An important factor that affects turnover is the overall character of the local labor market. When the local labor market (for registered nurses) at a particular facility has more jobs available (M1), when applicants have greater mobility between existing jobs (M2), and when the supply of suitable applicants is relatively low (M3), turnover may be increased.

\subsection{Analysis}

In order to assess the independent and combined effects of HRM practices on RN turnover, three systems (bundles) of HRM practices were constructed for each establishment: a technical HRM system, a quality-of-worklife HRM system, and a high-involvement HRM system. A fourth HRM system was 'artificially' constructed by combining the highinvolvement and quality-of-worklife system for each establishment (Model D). Four sequential ordinary least square (OLS) regressions were performed. In the first regression (Model A), the relative contribution of the control variables was run with RN turnover as the dependent variable. In the second regression (Model B), the quality-of-life HRM system and the control variables were run. In the third regression (Model C), the control variables were combined Published by Sciedu Press with our high-involvement HRM system, while in the fourth regression (Model D), our combined quality-of-worklife and high-involvement HRM system were added to the control variables.

Table 1. Healthcare Establishment Characteristics

\begin{tabular}{|c|c|c|}
\hline & $\begin{array}{l}\text { Hospital } \\
(n=232) \\
\text { Mean/StD }\end{array}$ & $\begin{array}{l}\text { LTC Facility } \\
(n=473) \\
\text { Mean/StD }\end{array}$ \\
\hline \multicolumn{3}{|l|}{ Establishment Characteristics } \\
\hline Establishment size (\#beds) & $219.3 / 295.3$ & 111.0/105.0 \\
\hline Establishment location score* & $3.08 / 1.19$ & $2.94 / 1.26$ \\
\hline Formal HRM department ${ }^{\#}$ & $0.92 / 0.28$ & $0.50 / 0.52$ \\
\hline RN turnover score ${ }^{\dagger}$ & $2.04 / 0.69$ & $1.68 / 0.86$ \\
\hline \multicolumn{3}{|c|}{ Technical HRM Practices (\% of nurses covered) } \\
\hline $\begin{array}{l}\text { Orientation program (new } \\
\text { hires) }\end{array}$ & $96.8 / 12.5$ & $97.7 / 11.4$ \\
\hline Written job descriptions & $92.6 / 20.0$ & $97.1 / 11.8$ \\
\hline $\begin{array}{l}\text { Formal performance appraisal } \\
\text { system }\end{array}$ & $79.2 / 31.7$ & $84.9 / 30.7$ \\
\hline Formal job evaluations & $62.2 / 40.8$ & $67.7 / 43.1$ \\
\hline Realistic job previews & $42.8 / 41.0$ & 48.1/46.6 \\
\hline Employment selection tests & $30.3 / 33.2$ & $26.5 / 42.2$ \\
\hline $\begin{array}{l}\text { Minority recruitment/retention } \\
\text { policy }\end{array}$ & 22.1/38.6 & 23.0/37.2 \\
\hline Drug testing policy & $4.0 / 17.5$ & $0.9 / 8.0$ \\
\hline \multicolumn{3}{|c|}{ Quality-of-Worklife HRM Practices (\% of nurses covered) } \\
\hline Employee assistance program & $93.3 / 22.3$ & $60.4 / 47.2$ \\
\hline Job sharing & $35.7 / 37.6$ & $27.2 / 39.2$ \\
\hline Internal promotion policy & $31.8 / 40.8$ & $41.0 / 44.8$ \\
\hline Flexible work hours & $30.3 / 40.9$ & $31.6 / 38.8$ \\
\hline Employee career counseling & $26.8 / 38.0$ & 13.9/31.9 \\
\hline Self-scheduling system & 20.9/31.1 & $13.7 / 30.8$ \\
\hline No layoff policy & 9.6/28.1 & $14.5 / 33.5$ \\
\hline Child care program & $8.5 / 24.1$ & $1.3 / 11.2$ \\
\hline \multicolumn{3}{|c|}{ High-Involvement HRM Practices ( $\%$ of nurses covered) } \\
\hline Employee recognition system & $74.3 / 37.9$ & 75.6/39.9 \\
\hline Quality improvement teams & $70.2 / 35.7$ & $72.3 / 40.0$ \\
\hline Employee attitude surveys & $60.4 / 42.9$ & $61.0 / 46.0$ \\
\hline Employee suggestion system & $49.4 / 43.4$ & $73.1 / 40.1$ \\
\hline Shared governance & $25.7 / 35.0$ & 21.3/36.4 \\
\hline $\begin{array}{l}\text { Job enlargement/job } \\
\text { enrichment }\end{array}$ & $16.9 / 27.4$ & 23.0/37.2 \\
\hline Self-managed teams & $16.7 / 29.3$ & $27.2 / 39.2$ \\
\hline Incentive based/merit pay & $5.5 / 19.0$ & $7.6 / 24.6$ \\
\hline
\end{tabular}

\section{Results}

Table 1 shows the demographic characteristics of the nursing homes and hospitals in the study. Approximately one-third of the establishments in this study are hospitals. Hospitals in our sample tend to be larger than long-term care establishments ( 219 beds versus 111 beds). The turnover rates for registered nurses vary across sites, but nursing homes generally reported lower RN turnover than hospitals. However, RNs constitute a much smaller percentage of total employed nurses in nursing homes. The human resource management function is more likely to be formalized in hospitals than in 
long term care organizations, where only about one-half of establishments have personnel departments. Results show, for instance, that almost $21 \%$ of nursing staff in hospitals use self-scheduling in comparison to about $14 \%$ of nursing staff in long-term care facilities.

To examine the independent effect for each type of HRM system on voluntary RN turnover, a four-stage hierarchical regression analysis was run to examine the independent contribution of each type of HRM system on voluntary turnover (see Table 2). In order to increase the statistical power for estimating the impact of a HRM practice system on turnover, hospitals and nursing home facilities were combined in our analysis, while facility type was controlled in the analysis. The 'Base' model represents the overall contribution of our control variables, which in total explains about $6 \%$ of the variance for the dependent variable, facility RN turnover. Our test results (see Model A) show that the technical HRM practice system do not show a statistically significant association with RN turnover. This finding is consistent with hypothesis one. The independent contribution of our quality-of-worklife HRM system (Model B) and the high-involvement HRM system (Model C) show a modest but statistically significant reduction in voluntary $\mathrm{RN}$ turnover $(p<.01)$. These findings provided confirmation of hypothesis two and hypothesis three. However, the magnitude of the association is quite modest. Hypothesis D predicted an 'additive effect' between for these HRM practice systems. Implicit in this characterization is the contention that the more HRM practices comprising a HRM system, the better. This was confirmed as the strength of inverse statistical association was stronger as well as the degree of statistical significance $(p<.005)$.

Table 2. OLS Regression Results for Establishment Voluntary Turnover

\begin{tabular}{|c|c|c|c|c|c|}
\hline Control Variables & Base & Model A & Model B & Model C & Model D \\
\hline \multicolumn{6}{|l|}{ Establishment Factors } \\
\hline Establishment size (In beds) & $.04(.05)$ & $.04(.05)$ & $.05(.05)$ & $.04(.05)$ & $.05(.05)$ \\
\hline Establishment location & $.00(.03)$ & $.00(.03)$ & $.00(.03)$ & $.00(.03)$ & $.00(.03)$ \\
\hline Establishment type & $-.33^{* * *}(.07)$ & $-.33^{* * *}(.08)$ & $-.35^{* * *}(.08)$ & $-.31^{* * *}(.08)$ & $-.33^{* * *}(.08)$ \\
\hline Formal HR department & $.09(.07)$ & $.05(.07)$ & $.08(.07)$ & $.06(.07)$ & $.08(.07)$ \\
\hline \multicolumn{6}{|l|}{ Local Market Factors } \\
\hline RN job supply (M1) & $-.01(.02)$ & $-.01(.02)$ & $-.01(.02)$ & $-.01(.02)$ & $-.01(.02)$ \\
\hline RN mobility (M2) & $.07^{* *}(.02)$ & $.07^{* *}(.03)$ & $.08^{* *}(.03)$ & $.08^{* *}(.03)$ & $.08^{* *}(.02)$ \\
\hline RN supply (M3) & $-.07^{* *}(.02)$ & $-.07^{* *}(.02)$ & $-.07^{* *}(.02)$ & $-.06^{* *}(.02)$ & $-.06^{* *}(.02)$ \\
\hline \multicolumn{6}{|l|}{ HRM Systems } \\
\hline A. Technical HRM system & & $-.01(.07)$ & & & \\
\hline B. Quality-of-worklife HRM system & & & $-.15^{*}(.07)$ & & \\
\hline C. High-involvement HRM system & & & & $-.14^{*}(.05)$ & \\
\hline D. Combined (QWL + HI) HRM system & & & & & $-.21^{* *}(.07)$ \\
\hline Constant & $2.00^{* * *}(.26)$ & $1.96^{* * *}(.28)$ & $2.05^{* * *}(.27)$ & $2.06^{* * *}(.27)$ & $2.10^{* * *}(.27)$ \\
\hline Adjusted R-square & .062 & .059 & .067 & .069 & .072 \\
\hline$\Delta-\mathrm{R}$ & --- & -.003 & -.005 & -.007 & .010 \\
\hline F-statistic & $7.02^{* * *}$ & $5.87^{* * *}$ & $6.56^{* * *}$ & $6.73^{* * *}$ & $7.01^{* * *}$ \\
\hline
\end{tabular}

Regression coefficient with standard errors in parenthesis: ${ }^{*} p<.01 ;{ }^{* *} p<.005 ;{ }^{* * *} p<.001$

\section{Discussion}

Our results show that healthcare organizations which adopt HRM systems that emphasize nurse- and family-centered employment practices and which adopt HRM systems that promote high-involvement work practices are associated with lower facility RN turnover. Our technical HRM system was not found to have an association with RN turnover. Our results are fully consistent with a 'universalistic perspective' that predict a 'reinforcing effect' with the addition of more HRM practices. While our study hypotheses are confirmed, the overall strength of the association that is observed appears to be quite modest, a finding which suggests that other factors (identified earlier) potentially play a greater role in impacting nurse turnover rates. Nevertheless, we should not discount the role of human resource management policies and practices to construct an institutional environmental in which nurses practice their craft.

\section{Study limitations}

Results provide general support for our study hypotheses. Nevertheless, there are a number of limitations that require elaboration. ${ }^{[39]}$ First, the data collected are from nurse managers who are reporting on conditions in their establishments. Since the dataset is assembled from a single source, common methods variance has the potential to confound results. ${ }^{[40]}$ Single respondent bias also limits our ability to generalize findings as nurse managers may not always be in the best 
judge with respect to the presence or absence of particular employment practices that are operational. Second, our measures of HRM employment and workplace practices are somewhat subjective and depend upon the perception and bias of respondents. For example, study participants were asked to indicate the degree to which a particular HRM practice is "embedded" in their organization by estimating the number of nurses covered by such practice. Even though a particular practice or policy has been adopted by an establishment, its manifestation may not resemble the practice that has been adopted in another organization. For instance, a selfscheduling system may be quite distinct with respect to its particular features making comparison with a self-scheduling approach that has been implemented in another establishment. Third, it is important to distinguish between HRM practices that are "intended" or believed to have been implemented, from those that are actually implemented. ${ }^{[41]}$ While HRM systems may be designed at the organizational level, many are implemented at the workplace level by supervisors who have varying degrees of understanding and ability to reflect (and implement) original intent.

Fourth, there is no real agreement with respect to which specific practice actually belongs to a particular HRM practice system. The three types of HRM systems examined in this research represent somewhat 'artificial' constructions that in reality defy simple characterizations. For example, nurse self-scheduling is generally considered a high-involvement work practice because it increases employee participation, involvement and commitment, but could also be a quality-ofworklife practice because it is employee- and family-friendly and thus generally preferred by nurses because it allows them to schedule work in ways that better accommodate personal and family situations. In this study, our overall construction of HRM systems is generally consistent with a 'universalist perspective' with respect to the relationship of HRM practices to our performance outcome measure (facility RN turnover). This perspective suggests an 'additive effect' for each practice- that is to say, having more HRM practices in a system (bundle) is inherently 'better' than having fewer practices. Yet, this may not be true in instances where 'deadly connections' results as certain practices are placed together in one HRM system. For instance, individual incentive or merit pay is usually considered to be a high-involvement work practice, yet its inclusion in a HRM system may undercut employee collaboration and teamwork while promoting competition among employees. Fifth, the level of 'internal fit' between the various individual HRM practices comprising a particular HRM system may not be the only element of structural fit required. Indeed, the ability of HRM practices to impact performance or lower turnover may not occur unless it aligns or fits with a number of other factors, including organizational strategy and workplace culture. ${ }^{[42]}$ HRM practices may have the potential to reduce turnover, but only when they 'align with' or 'fit' the organization's strategy or its culture. Sixth, our analysis is retrospective and reflects assessments at one particular point in time. Our analysis does not allow for us to infer causality between study variables. We are unable to say that a particular HRM system 'causes' a reduction in turnover, only that it demonstrates an association with it. Finally, our study reports on existing practices and conditions in Canadian healthcare organizations. As such, we are unable to generalize our findings to organizations in other jurisdictions and industries.

\section{Conclusion}

Although somewhat preliminary, our results are consistent with previous research which shows an important relationship between the application of human resource management practices and employee turnover. ${ }^{[43]}$ Given the high cost of nursing turnover, it is imperative for healthcare organizations to adopt HRM practices that have the potential to reduce the rate by which nurses leave their employ. This study has showed that, although the contribution of practice systems to reduce voluntary turnover is modest, human resource managers need to be cognizant of the role that employment practices and policies play in creating a workplace that both fully engages nurses as well as facilitates their work-family interface.

\section{CONFlicts of InTEREST Disclosure}

The authors have no potential conflicts of interest.

\section{REFERENCES}

[1] Hayes LJ, O’Brien-Pallas L, Duffield C, et al. Nurse turnover: a literature review - an update. International Journal of Nursing Studies 2012; 49: 887-905. PMid:22019402. http://dx.doi.org/10.10 16/j.ijnurstu.2011.10.001

[2] Hayes LJ, O'Brien-Pallas L, Duffield C, et al. Nurse turnover: a literature review. International Journal of Nursing Studies. 2006; 43:
237-263. PMid:15878771. http://dx.doi.org/10.1016/j.ijn urstu.2005.02.007

[3] Baumann A. The impact of turnover and the benefit of stability in the nursing workforce. International Councils for Nurses 2010, Geneva, Switzerland.

[4] Duffield CM, Roche MA, Homer C, et al. A comparative review of nurse turnover rates and costs across countries. Journal of Ad- 
vanced Nursing. 2014; 70(12): 2703-2712. PMid:25052582. http: //dx.doi.org/10.1111/jan.12483

[5] Li Y, Jones CB. A literature review of nursing turnover costs. Journal of Nursing Management. 2013; 21: 405-418. PMid:23406301. http://dx.doi.org/10.1111/jan.12483h

[6] Jones CB. Staff nurse turnover costs: Part I, a conceptual model. Journal of Nursing Administration. 1990; 20(4): 18-23. PMid:2109052.

[7] Jones CB. Staff nurse turnover costs: Part II, measurement and results. Journal of Nursing Administration. 1990; 20(5): 27-32. PMid:2271020.

[8] Tai TWC, Bame SI, Robinson CD. Review of nursing turnover research, 1977-1996. Social Science and Medicine. 1998; 47(12): 19051924. PMid:10075235. http://dx.doi.org/10.1016/S0277-9 536 (98) 00333-5

[9] Duffield CM, Roche MA, O'Brien-Pallas L, et al. Implications of staff 'churn' for nurse managers, staff and patients. Nursing Economics. 2009; 27(2): 103-110. PMid:19492774.

[10] Evans J, Brown A, Baker GR. Intellectual capital in the healthcare sector: a systematic review and critique of the literature. BMC Health Services Research. 2015; 15: 556. PMid:26670123. http://dx.doi.org/10.1186/s12913-015-1234-0

[11] Rondeau KV, Williams ES, Wagar TH. Developing human capital: what is the impact on nursing turnover? Journal of Nursing Management. 2009; 17(6): 739-748. PMid:19694917. http: //dx.doi.org/10.1111/j.1365-2834.2009.00988.x

[12] Rondeau KV, Williams ES, Wagar TH. Turnover and vacancy rates for registered nurses: do local labour market factors matter? Health Care Management Review. 2008; 33(1): 69-78. PMid:18091446. http: //dx.doi.org/10.1097/01.HMR.0000304494.87898.bc

[13] Stone PW, Larson EL, Mooney-Kane C, et al. Organizational climate and intensive care unit nurses' intention to leave. Critical Care Medicine. 2006; 34(7): 1907-1912. PMid:16625126. http: //dx.doi.org/10.1097/01.CCM.0000218411.53557.29

[14] Irvine D, Evans M. Job satisfaction and turnover among nurses: integrating research findings across studies. Nursing Research. 1995; 44(4): 246-253. PMid:7624236.

[15] Price JL, Mueller CW. A causal model of turnover for nurses. Academy of Management Journal. 1981; 24(3): 543-565. http: //dx.doi.org/10.2307/255574

[16] Takese M, Yamashita N, Oba K. Nurses' leaving intentions: antecedents and mediating factors. Journal of Advanced Nursing. 2008 62(3): 295-306. PMid:18426454. http://dx.doi.org/10.1111 /j.1365-2648.2007.04554.x

[17] Crossley CD, Bennet RJ, Jex SM, et al. Development of a global measure of ob embeddedness and integration into a traditional model of voluntary turnover. Journal of Applied Psychology. 2007; 92(4): 1031-1042. PMid:17638463. http://dx.doi.org/10.1037/002 $1-9010.92 .4 .1031$

[18] Raup GH. The impact of ED nurse manager leadership style on staff nurse turnover and patient satisfaction in academic health center hospitals. Journal of Emergency Nursing. 2008; 34(5): 403 409. PMid:18804712. http://dx.doi.org/10.1016/j.jen.2 007.08 .020

[19] O'Brien-Pallas L, Tomblin Murphy G, Shamian J, et al. Impact and determinants of nurse turnover: a pan-Canadian study. Journal of Nursing Management. 2010; 18(8): 1073-1086. PMid:21073578 http://dx.doi.org/10.1111/j.1365-2834.2010.01167.x

[20] $\mathrm{Chu} \mathrm{CH}$, Wodchis WP, McGilton KS. Turnover of regulated nurses in long-term care facilities. Journal of Nursing Management. 2014; 22: 553-562. PMid:25041798. http://dx.doi.org/10.1111/j onm. 12031
[21] Paauwe J, Guest D, Wright P. HRM and performance. Achievements and challenges, 2013; Wiley: West Sussex, UK.

[22] Huselid MA. The impact of human resource management practices on turnover, productivity, and corporate financial performance. Academy of Management Journal. 1995; 38(3): 635-672. http: $/ / d x$.doi.org/10.2307/256741

[23] Combs J, Liu Y, Hall A, et al. How much do high-performance work practices matter? A meta-analysis of their effects on organizational performance. Personnel Psychology. 2006; 59(3): 501-528. http://dx.doi.org/10.1111/j.1744-6570.2006.00045.x

[24] Delery J, Shaw J. The strategic management of people in work organizations: review, synthesis and extension. Research in Personnel and Human Resources Management. 2001; 20: 165-197. http://dx.doi.org/10.1016/S0742-7301(01) 20003-6

[25] MacDuffie JP. Human resource bundles and manufacturing performance: organizational logic, and flexible production systems in the world auto industry. Industrial and Labor Relations Review. 1995; 48(2): 197-221. http://dx.doi.org/10.1177/0019793995048 00201

[26] Wright PM, Gardner TM, Moynihan LM, et al. The relationship between HR practices and firm performance: examining causal order Personnel Psychology. 2005; 58(2): 409-446. http://dx. doi.org /10.1111/j.1744-6570.2005.00487.x

[27] Toh S, Morgeson F, Campion M. Human resource configurations: investigating fit with the organizational context. Journal of Applied Psychology. 2008; 93(4): 864-882. PMid:18642989. http: //dx.doi.org/10.1037/0021-9010.93.4.864

[28] Strachota E, Normandin P, O'Brien N, et al. Reasons registered nurses leave or change employment status. Journal of Nursing Administration. 2003; 33(2): 111-117. PMid:12584464. http://dx.d oi .org/10.1097/00005110-200302000-00008

[29] Shader K, Broome M, Broome CD, et al. Factors influencing satisfaction and anticipated turnover for nurses in an academic medical center. Journal of Nursing Administration. 2001; 31(4): 210-216. PMid:11324334. http://dx.doi.org/10.1097/00005110-200 104000-00010

[30] Yoder LH. Staff nurses' career development relationships and selfreports of professionalism, job satisfaction, and intent to stay. Nurse Researcher. 1995; 44(5): 290-297. PMid:7567485.

[31] Kane D. Job-sharing: a retention strategy for nurses. Canadian Journal of Nursing Leadership. 1999; 12(4): 16-22. PMid:11094939. http://dx.doi.org/10.12927/cjnl.1999.16296

[32] Orgambidez-Ramos A, Borrego-Alés Y. Empowering employees: structural empowerment as antecedent of job satisfaction in University settings. Psychological Thought. 2014; 7(1): 28-36. http: //dx.doi.org/10.5964/psyct.v7i1.88

[33] Laschinger HK, Finegan JE, Shamian J, et al. A longitudinal analysis of the impact of workplace empowerment on work satisfaction. Journal of Organizational Behavior. 2004; 25(4): 527-545. http://dx.doi.org/10.1002/job. 256

[34] Hauck A, Quinn Griffith MT, Fitzpatrick JJ. Structural empowerment and anticipated turnover among critical care nurses. Journal of Nursing Management. 2011; 19(2): 269-276. PMid:21375631. http://dx.doi.org/10.1111/j.1365-2834.2011.01205.x

[35] Holtom BC, O'Neill BS. Job embeddedness: a theoretical foundation for developing a comprehensive nurse retention plan. Journal of Nursing Administration. 2004; 34(5): 216-227. PMid:15167418.

[36] Anderson RA, Corazzini KN, McDaniel Jr. RR. Complexity science and the dynamics of climate and communication: reducing nursing home turnover. Gerontologist. 2004; 44(3): 378-388. PMid:15197292. http://dx.doi.org/10.1093/geront/44.3 .378 
[37] Pfeffer J. The human equation: building profits by putting people first 1998; Boston: Harvard Business School Press.

[38] Canadian Healthcare Association. Guide to Canadian healthcare facilities, 2001-2002 2001; CHA Press: Ottawa, Ont.

[39] Gerhart B. Research on human resources and effectiveness: some methodological challenges. In: J. Paauwe, D., Guest, P. Wright, HRM and performance. Achievements and challenges; Wiley: West Sussex, UK; 2013. p. 149-171.

[40] Doty DH, Glick WH. Does common methods variance really bias results? Organization Research Methods. 1998; 1(4): 374-406.
[41] Wright PM, Nishii LH. Strategic HRM and organizational behaviour: integrating multiple levels of analysis. In: J Paauwe, D Guest, P Wright, HRM and performance. Achievements and challenges, Wiley: West Sussex, UK; 2013. p. 97-110.

[42] Paauwe J, Boon C, Boselie P, et al. Reconceptualizing fit in strategic human resource management: 'Lost in translation?' In: J Paauwe, D Guest, P Wright, HRM and performance. Achievements and challenges; Wiley: West Sussex, UK; 2013. p. 61-77.

[43] Batt R, Colvin AJS. An employment systems approach to turnover: human resource practices, quits, dismissals, and performance. Academy of Management Journal. 2011; 54(4): 695-717. http: //dx.doi.org/10.5465/AMJ.2011.64869448 